\title{
OPIEKUNKA DYKTATORA. LOSY HELENY KIRKOROWEJ (1828-1900) W POWSTANIU STYCZNIOWYM I NA ZESLANIU SYBERYJSKIM
}

W śród rzeszy zesłańców skazanych w procesie Romualda Traugutta i członków Rządu Narodowego na katorgę syberyjską, postacią nietuzinkową była aktorka sceny wileńskiej i krakowskiej, Helena z Majewskich Kirkorowa. Kariera aktorska, romans z Władysławem Syrokomlą, następnie pełne oddanie i poświęcenie się sprawie narodowej w czasie powstania 1863 r., stanowić mogą kanwę interesującej powieści ${ }^{1}$. Kirkorowa, wśród potomnych wywoływała skrajne emocje i oceny, od uwielbienia po negację. Bibianna Moraczewska, literatka i działaczka społeczna, nazywała ją komediantką i awanturnicą, ironicznie i złośliwie porównując do Dulcynei z Toboso ${ }^{2}$, natomiast Andrzej E. Koźmian, konserwatywny polityk i publicysta, widział w niej nawet czarownicę $^{3}$ Z k kolei Marian Dubiecki twierdził, że była to kobieta ,inteligentna i sprytem niepospolitym obdarzona"4. Podobnych opinii można spotkać wiele w literaturze pamiętnikarskiej.

Helena Kirkorowa przyszła na świat 19 maja 1828 r. w Starej Wsi w powiecie rawskim, w rodzinie Ignacego Majewskiego, dzierżawcy dóbr i Ludwiki z Wierzbickich. Ojciec w chwili narodzin córki, której na chrzcie dano imiona Petronela Helena, był pisarzem prowentowym, następnie dzierżawcą majątku w powiecie rawskim. Natomiast matka, Ludwika z Wierzbickich, wywodzić się miała z rodziny ziemiańskiej spod Płocka ${ }^{5}$. O jej rodzinie niewiele zachowało się informacji.

1 S. Kirkor, Od Syrokomli do Traugutta. Tragiczna dola Heleny Kirkorowej, „Wiadomości” 1962, nr 51/52, s. 4-5; tenże, Na Syberii. Dalszy przyczynek do historii życia Heleny Kirkorowej, tamże, 1965, nr 51-52, s. 4-5. W 1978 r. Stanisław Kirkor poświęcił H. Kirkorowej powieść pt. Przeszłość umiera dwa razy. Powieść prawdziwa (Kraków 1978). Ostatnio sylwetkę aktorki przypominała Joanna Puchalska (Kobiety, które zmienity świat, Warszawa 2016, s. 150-175).

2 B. Moraczewska, Dziennik, Poznań 1911, s. 65.

3 A. E. Koźmian, Listy, t. 3, Lwów 1894, s. 192.

${ }_{4}$ M. Dubiecki, Romuald Traugutt i jego dyktatura podczas powstania styczniowego 1863-1864, Kijów 1911, s. 137.

5 Archiwum Państwowe w Piotrkowie Trybunalskim. Oddział w Tomaszowie Mazowieckim, Akta Stanu Cywilnego Parafii Rzymskokatolickiej w Białej, sygn. 5, k. 59 (akt urodzenia nr 118). 
Wiadomo, że miała brata Jana, który był oficerem armii rosyjskiej ${ }^{6}$. Córka Ignacego i Ludwiki Majewskich początkowo oddana została do szkoły baletu, jednak nie czując w sobie tancerki, zaczęła zdobywać tajniki sztuki aktorskiej w warszawskiej Szkole Dramatycznej, działającej pod dyrekcją Bonawentury Kudlicza? .

Karierę aktorską rozpoczęła bardzo szybko, bo już w 1843 r. Józef Surewicz, wileński reżyser i aktor, zabrał ją wraz z Emilią Markowską do Wilna, jako jedną z lepszych uczennic Szkoły Dramatycznej. Młodziutka Majewska bardzo szybko potrafiła się tu odnaleźć i wraz z zespołem teatru wileńskiego wyjeżdżała na występy m.in. do Druskiennik. Początkowo grała role chłopięce, naiwne i liryczne, m. in. Józefka w „Niedorostku” Denisa I. Fonwizina, Pazia w sztuce „Henryk II” Aleksandra Dumasa-ojca. Bardzo szybko zaczęto ją obsadzać w rolach amantek, m. in. Julii („Romeo i Julia” Williama Szekspira), Panny de Belle Isle („Panna de Belle Isle” Aleksandra Dumasa-ojca). Swobodna gra aktorska, dobra wymowa oraz uroda bardzo szybko przysporzyły jej wielu wielbicieli $^{8}$. Emil Deryng, artysta dramatyczny, wileński pedagog sceniczny, pisał o niej, że jest

płocha, lekka, żywa, lecz z najlepszym sercem, z odwagą i bezgranicznym poświęceniem, byłaby mogła wszędzie zaskarbić sobie życzliwość i względy, gdyby nie ciągała chęć przemiany, gdyby wreszcie i nie okoliczności sprzyjającej ku temu [...]. Nie cierpiała doradców, może właśnie dlatego, że proszeni i nieproszeni narzucali się jej z radami ${ }^{9}$.

Młodziutka Majewska miała mnóstwo wielbicieli z wyższych sfer towarzyskich w Wilnie. Szczególną opieką otaczał ją ponoć Aleksander de Roberti, prezes wileńskiej Izby Skarbowej. Zdaniem rosyjskiego publicysty i historyka Mikołaja Berga, to właśnie on wydać ją miał za mąż za Adama Honorego Kirkora, archeologa, wydawcę, publicystę, redaktora i recenzenta teatralnego z Wilna ${ }^{10}$. Kirkor był człowiekiem zamożnym, posiadał rozległe znajomości w wileńskim świecie naukowym, literackim a także politycznym. Współpracował z Ludwikiem Kondratowiczem (Władysławem Syrokomlą), Wincentym Korotyńskim, Józefem A. Łepkowskim, Lucjanem Siemieńskim. Dzięki ugodowej postawie wobec władz rosyjskich zdobył stanowisko członka rzeczywistego wileńskiego

${ }^{6}$ F. Ramotowska, Kirkorowa 2. v. Piórowa z Majewskich Petronela Helena, działaczka powstania 1863 r., [w:] Polski Stownik Biograficzny, t. 12, Wrocław-Kraków-Warszawa 1966-1967, s. $483-485$.

7 Z. Wilski, Polskie szkolnictwo teatralne 1811-1944, Wrocław-Warszawa-Kraków-Gdańsk 1978, s. 101-105.

${ }^{8}$ Stownik teatru polskiego 1765-1965, Warszawa 1973, s. 410.

${ }^{9}$ Biblioteka Narodowa w Warszawie [dalej: BN], E. Deryng, Z pamiętników aktora wileńskiego, rkps akc. 7882, k. 43.

${ }^{10}$ M. Berg, Zapiski o powstaniu polskim 1863 i 1864 roku i poprzedzajacej powstanie epoce demonstracji od 1856 r., t. 3, Kraków 1899, s. 313. 
Komitetu Statystycznego ${ }^{11}$. W 1846 r. Helena Kirkorowa opuściła scenę teatralną. Dzięki znajomościom męża poznała m.in. dziennikarza Wacława Przybylskiego i Władysława Syrokomlę, którzy mieli zaważyć na jej dalszym życiu ${ }^{12}$.

Syrokomla wspólnie z Kirkorem przygotowywał mający niebawem ukazywać się „,Tygodnik Literacki Wileński”. W związku z tym przedsięwzięciem Kirkor zmuszony był na dłużej wyprawiać się do Petersburga, pozostawiając w Wilnie swoje plenipotencje Syrokomli ${ }^{13}$. Wtedy też, a ściślej na przełomie 1856 i 1857 r., nastąpiło ,zbliżenie” poety z żoną Kirkora. Romans wywołał niemały skandal na Litwie, spotkał się z ostrą krytyką, mówiono o nim we wszystkich wileńskich salonach. Władysław Korotyński, badacz twórczości Syrokomli, po latach stwierdził, że Kirkorowa jako

kobieta nie tylko urodziwa, ale niepospolitego umysłu i hartu woli, będąc aktorką z zawodu i powołania, traktowała tę miłość jak przelotne wrażenie, jak chlubę wobec świata, jak szczebel w karierze artystycznej. Syrokomla zaś ukochał ją całą duszą, całą siłą długo uśpionego uczucia ${ }^{14}$.

Kirkorowa opuściła męża na zawsze w grudniu 1857 r.

Przenosząc się do Krakowa, gdzie już w pierwszych dniach stycznia 1858 r. zamieszkała z owdowiałą matką, zaopatrzona została w list Syrokomli do Aleksandra Szukiewicza, członka redakcji krakowskiego „Czasu”, w którym poeta prosił dziennikarza o życzliwą opiekę nad aktorką.

Pani Kirkor (z domu Majewska) wskutek okoliczności, które długo by wypisywać, a które za widzeniem się opowiem, zmuszona rozstać z mężem wyjeżdża do Krakowa celem wstąpienia do teatru. Zawód sceniczny - jak dowodził W. Syrokomla - nie jest dla niej obcy i jedna z pierwszych uczennicy Szkoły Dramatycznej w Warszawie za czasów Kudlicza, potem w Wilnie z powodzeniem grająca, ma prawo oczekiwać, że Kraków przyjmie ją, jeżeli nie oklaskami, na które potrzeba zasłużyć, to ze współczuciem, które ośmieli do pracy. Nie wątpię, że redakcja „Czasu” ma swój wpływ na teatr i ułatwienie występu Pannie Majewskiej (pod tym nazwiskiem chce grać) ${ }^{15}$.

Aktorka bardzo szybko odnalazła się w Krakowie. Poznała tutaj m.in. Tadeusza Komara, absolwenta Uniwersytetu Kijowskiego, poetę, autora wielu wierszy i pieśni lirycznych, krążących już wówczas w odpisach, deklamowanych i śpiewanych przez młodzież.

${ }^{11}$ M. Brensztajn, Adam Honory Kirkor. Wydawca, redaktor $i$ wtaściciel drukarni $w$ Wilnie od roku 1834 do 1867, Wilno 1930.

${ }^{12}$ F. Ramotowska, dz. cyt., s. 484.

${ }_{13}$ M. Brensztajn, dz. cyt., s. 20-21; F. Fornalczyk, Hardy lirnik wioskowy. Studium o Kondratowiczu - Syrokomli, Poznań 1979, s. 371.

${ }^{14}$ L. Kondratowicz (W. Syrokomla), Podróż swojaka po swojszczyźnie, z rękopisu ogłosił Władysław Korotyński, Warszawa 1914, s. XIV.

${ }^{15}$ Zakład Narodowy im. Ossolińskich we Wrocławiu, Korespondencja Aleksandra Szukiewicza, redaktora „Czasu” i „Jutrzenki”. Listy od różnych osób, rkps II 6531, k. 487. 
Zaangażowana została w teatrze Juliusza Pfeifra. Już w lutym 1858 r. wystąpiła w roli Tysbe w sztuce Victora Hugo Angelo Malipieri, tyran Padwy, zdobywając wielki aplauz widzów. Gra aktorska Kirkorowej - jak napisał Karol Estreicher:

wyróżniała się od gry innych artystek wielką naturalnością, spokojem i cieniowaniem. Bez szamotania się i krzykliwości, osiągała większe efekty niż inne artystki, które grywały, wyszukując efektu, gwałtownością dykcji i siłą akcji ${ }^{16}$.

Krakowski „Czas” opublikował kilka recenzji z jej występów. Pisał w nich m.in. że Kirkorowa „pojęła i wykonała swą rolę z pewnością i sztuką, dowodzącą nie tylko talentu, lecz i znakomitego wykształcenia artystycznego". W dalszej części recenzji podkreślano jej

rysy mniej regularne, lecz pełne duchowego wyrazu, odzwierciedlające żywo uczucia duszy; głos niekiedy twardy, lecz silny, wyraźny i zrozumiały, deklamację właściwą, bez żadnej aktorskiej przesady [...], kunsztowne umiarkowanie w prowadzeniu całej roli od początku do końca ${ }^{17}$.

W połowie 1858 r. Kirkorowa spotkała się w Poznaniu z Syrokomlą. Doszło do kolejnego skandalu, który odbił się głośnym echem w salonach towarzyskich. Podczas roli w dramacie Ignacego Humnickiego Żótkiewski pod Cecora, w ostatniej scenie dramatu Majewska - jak pisze Bibianna Moraczewska:

nie na żarty się przebiła, bo utopiła puginał tak głęboko w piersiach, że się krew polała [...]. Syrokomla siedział pod moją lożą prawie, ujrzawszy krew kochanki i widząc, że ją wylała, żeby z nim dłużej pozostać, załamał z rozpaczy ręce, przycisnął do skroni i wybiegł za kulisy ${ }^{18}$.

Uszczypliwy Andrzej E. Koźmian donosił rodzinie w liście, że Majewska „doskonale padła, zemdlała i pierwszy raz w życiu wybornie grała" ${ }^{19}$. Wywołało to kolejną falę plotek, pomówień. Syrokomla pozostał z ukochaną w Poznaniu do końca jej rekonwalescencji, a gdy wyzdrowiała, poeta pojechał za Kirkorową do Piotrkowa, gdzie spotkali się już po raz ostatni. Syrokomla, zawiadomiony o ciężkiej chorobie ojca, musiał wyjechać. W ślad za nim Kirkorowa wysłała list, którym zerwała dotychczasową znajomość. Przyczyny tego kroku nie są znane. Poeta wkrótce popadł w depresję, z której nie podniósł się aż do śmierci ${ }^{20}$.

Kirkorowa grała w Krakowie jeszcze około półtora roku. Występowała przeważnie w rolach głównych, jako Amelia w Mazepie Juliusza Słowackiego, jako Adrienne Lecouvreur w dramacie Eugène Scribe'a i Ernesta Legouvé ${ }^{1}$.

${ }^{16}$ K. Estreicher, Teatra w Polsce, t. 2, Kraków 1876, s. 545.

17 „Czas” 1858, nr 29, s. 3.

${ }^{18}$ B. Moraczewska, $d z$. cyt., s. 66.

19 A. E. Koźmian, dz. cyt., t. 3, s. 187.

${ }^{20}$ M. Witkowski, Syrokomli wycieczka po swojszczyźnie, [w:] Literackie przystanki nad Warta, pod red. Z. Szweykowskiego, Poznań 1962, s. 358-359; F. Ramotowska, dz. cyt., s. 484.

${ }^{21}$ F. Ramotowska, dz. cyt., s. 484. 
Była to - jak pisze M. Estreicherówna - rzeczywiście dobra aktorka, ale kapryśna i trudna w pożyciu, więc się niebawem poróżniła z Pfeifrem. Na wieść o jej ustąpieniu zebrali się wielbiciele thumnie w teatrze i gwałtownie ją wywoływali, chociaż w przedstawieniu nie brała udziału. Pfeifer w końcu wyszedł przed kurtynę, by uciszyć tumult, gdy jednak oznajmił, że Kirkorowa już do trupy nie należy, obrzucono go skorupami z jaj, a na następne przedstawienie przygotowano jeszcze energiczniejszą demonstrację, lecz policja do niej nie dopuściła. Wówczas młodzież rozpoczęła bojkot teatru, wobec czego Pfeifer zaangażował Majewską na następny sezon. Od razu na pierwszym przedstawieniu («Krakowiacy i górale») teatr tak się zapełnił, że zabrakło biletów nawet na parter i galerię 22 .

W lutym 1859 r. odegrano na jej benefis dramat historyczny Możnowładcy i sierota, napisany specjalnie w tym celu przez Syrokomlę. Aktorka i tym razem spotkała się z dobrym przyjęciem publiczności, chociaż w lwowskim „Dzienniku Literackim” w recenzji przedstawienia napisano, iż Kirkorowa „ma wyrobioną rutynę ruchów i deklamacji, która przyprowadza do nudy"23. Razem z trupą Pfeifra wyjeżdżała na gościnne występy do Poznania, Kalisza, Konina, Lublina, Łodzi i Piotrkowa. Wkrótce jednak poróżniwszy się z Pfeifrem, zwolennikiem gry deklamacyjnej, Kirkorowa opuściła scenę krakowską, przenosząc się do Warszawy, gdzie jednak nie zaangażowała się do teatru. Opuszczając podwawelski gród aktorka pozbywała się pamiątek związanych z Syrokomlą. Sprzedała wówczas m.in. rękopis dramatu Możnowładcy i sierota ${ }^{24}$. Zakupił go od artystki Ludwik Zarewicz, krakowski historyk i kolekcjoner, ofiarowując następnie Bibliotece Jagiellońskiej ${ }^{25}$.

Kirkorowa przybyła do Warszawy pod koniec sierpnia 1860 r. ${ }^{26}$ Wraz z owdowiałą matką zamieszkała przy ul. Krzywe Koło, później przy ul. Chmielnej, a po roku przeniosła się do mieszkania przy ul. Piwnej na Rynku Starego Miasta. Szybko włączyła się do przedpowstaniowego ruchu patriotycznego. Mikołaj Berg pisze, że aktorka

z całym zapałem przystąpiła do organizacji narodowej i korzystając z darów natury, która uczyniła ją miłą i pociągającą, oddawała wielkie usługi Rządowi Narodowemu jako agentka i kurierka, używana do przewożenia za granicę depesz i ustnych poleceń, co się jej zawsze udawało dzięki dobrym stosunkom z żandarmami i urzędnikami na komorach celnych ${ }^{27}$.

${ }^{22}$ M. Estreicherówna, Życie towarzyskie i obyczajowe Krakowa w latach 1848-63, t. 1, Kraków 1936, s. 165.

23 „Dziennik Literacki” 1859, nr 10, s. 123.

${ }^{24}$ F. Bielak, Skreślenia cenzora austriackiego w dramacie Syrokomli, „Silva Rerum” 1927, nr 4, s. 53.

${ }^{25}$ Inwentarz rękopisów Biblioteki Jagiellońskiej, cz. 1, Nr 6001-6500, oprac. A. Jałbrzykowska, J. Zathey, przy współudziale Z. Łagodowej, J. Tyszkowskiej, Kraków 1962, s. 28.

${ }^{26}$ Proces Romualda Traugutta i członków Rządu Narodowego. Akta Audytoriatu Polowego z lat 1863/1864, t. 2, cz. 1, pod red. E. Halicza, Warszawa 1960, s. 286 (zeznania H. Kirkorowej).

${ }^{27}$ M. Berg, dz. cyt., t. 3, s. 313. 
Zdaniem Walerego Przyborowskiego oprócz depesz przewoziła za granicę również pieniądze władz powstańczych ${ }^{28}$.

Kirkorowa w sprawach powierzanych jej przez organizację narodową jeździła do Krakowa i Wilna. W grudniu 1862 r. przybyła do Wilna.

\begin{abstract}
Przybrana w czarną, powłóczystą suknię - wspomina Emil Deryng - wznawia dawne znajomości, jest wszędzie, gdzie wcisnąć się może, i znika niepostrzeżenie, aby zdać relację ze swego pobytu w Wilnie tym, którzy ją upoważnili do działania w sprawie dobra ogółu, w sprawie narodowej [...]. Z dziwną zręcznością i spokojem twarzy umiała przewozić dane zlecenia. Pewnego dnia pojawiła się w Wilnie tak obładowana bronią, tajnymi papierami i pieniędzmi, że lada chwila należało się spodziewać smutnego wypadku. I tym razem jednak wywiązała się szczęśliwie. Powróciła do domu znużona, opadła z sił, lecz na duchu pełna nadziei, że nie upadnie sprawa w dobrej wierze poczęta. Nazajutrz odjechała koleją do Lublina, swobodna, wesoła, naznaczając spotkanie się w Warszawie, ponieważ za dwa lub trzy tygodnie najdalej przyrzekała sobie wystąpić w teatrze ${ }^{29}$.
\end{abstract}

Po wybuchu powstania Helena Kirkorowa bez reszty zaangażowała się w działalność konspiracyjną. Mieszkanie jej przy ul. Piwnej stało się bardzo szybko jednym z konspiracyjnych punktów organizacji narodowej. Przez jakiś czas mieszkał u niej Jan Kozieł Poklewski, referent Wydziału Wojny Rządu Narodowego i naczelnik wojskowy Warszawy oraz dr Karol Przybylski, brat Wacława, za pośrednictwem którego Kirkorowa utrzymywała kontakt z kierownictwem powstani $^{30}$. Bywał u niej także, poznany jeszcze w Krakowie, poeta Tadeusz Komar, zaangażowany w konspirację przedpowstaniową, współpracownik Jarosława Dąbrowskiego. Komar, przed ucieczką za granicę, zostawił w mieszkaniu Kirkorowej rewolwer oraz dokumenty władz narodowych ${ }^{31}$.

Niebawem też Wacław Przybylski powierzył opiece Kirkorowej Romualda Traugutta. W tym celu wynajął pięciopokojowe mieszkanie przy ul. Smolnej, w którym od 1 listopada 1863 r. zamieszkała Kirkorowa z matką oraz pięcioletnim chłopcem Władysławem, prawdopodobnie jej wychowankiem ${ }^{32}$, oraz Traugutt pod nazwiskiem Michała Czarneckiego. Dyktator zajmował dwa pokoje.

Kirkorowa - jak pisze Marian Dubiecki - o prawdziwym nazwisku dyktatora i jego rzeczywistym stanowisku w pracach powstańczych nie była świadomą. Jeżeli takiego wysokiego stanowiska lokatora domyślała się ta inteligentna, i sprytem niepospolitym obdarzona

${ }^{28}$ W. Przyborowski, Dzieje 1863 roku, t. 5, Kraków-Warszawa 1919, s. 238.

${ }^{29}$ BN, rkps akc. 7882, k. 46-47.

${ }^{30}$ F. Ramotowska, $d z$. cyt., s. 483.

${ }^{31}$ Proces Romualda Traugutta, t. 2, cz. 2, s. 270 (zeznania H. Kirkorowej).

${ }^{32}$ Kirkorowa w jednym z zeznań przed Komisją Śledczą powiedziała, że Władzio jest jej krewnym i przebywa u mniej na wychowaniu. Zob.: Proces Romualda Traugutta, t. 2, cz. 1, s. 287 (zeznania H. Kirkorowej). Natomiast Marian Dubiecki (dz. cyt., s. 132) twierdził, że chłopiec był synem aktorki. 
kobieta, to chyba już znacznie później, w ostatnich jego i swej zarazem wolności, w każdym jednak razie owo domyślanie się bardzo ogólnikowe być musiało ${ }^{33}$.

W oficynie posesji przy ul. Smolnej zamieszkał Marian Dubiecki, sekretarz Rusi, który pełnił także funkcję łącznika dyktatora.

Kirkorowa zajmowała się sprawami organizacji narodowej, natomiast jej matka prowadziła gospodarstwo domowe i kuchnię. W jej mieszkaniu przy ul. Smolnej bywali często Feliks Majewski, brat stryjeczny, kleryk seminarium duchownego, Artur Wołyński, sekretarz Wydziału Spraw Zagranicznych Rządu Narodowego, Józef Kajetan Janowski. Kirkorowa odbierała od swych łączniczek, Płacheckiej i Guzowskiej, papiery dla Traugutta oznaczone trzema krzyżykami ${ }^{34}$. Za ich pośrednictwem wysyłała jego polecenia, rozkazy, instrukcje. Znajomi jej nie mieli jednak dostępu do mieszkania Traugutta. Kirkorowa stała się więc jego rzeczywistą opiekunką.

Pilnowała jednak - jak pisze Marian Dubiecki - owego «Pana Michała», strzegła gorliwie jak oka w głowie, zabezpieczała jego spokój i chroniła od wszystkich, by najmniejszych niebezpieczeństw ${ }^{35}$.

Kirkorowa odbierała osobiście wszystkie dokumenty przeznaczone dla dyktatora, przez jej ręce przechodziły też dokumenty, które szły w świat powstańczy. Niekiedy sama zanosiła je do mieszkania doktora Włodzimierza Dybka ${ }^{36}$.

Dyktator dzięki bezgranicznej opiece Kirkorowej mógł bez przeszkód spotykać się z zaufanymi osobami, kierować dalszą walką, wydawać dyrektywy, rozporządzenia, odezwy, kierować korespondencję do komisarzy pełnomocnych, naczelników wojskowych i agentów dyplomatycznych. Kirkorowa, jak pisze Dubiecki, była

wszystkim, gdy chodziło o tę lub ową domową posługę w mieszkaniu dyktatora. Prace domowe dzieliła ze swą sędziwą matką, i oprócz niej do pokoju „Pana Michała”, nikt nie miał wstępu. Służącej, acz poczciwej i wiernej, wstęp zupełnie prawie był wzbroniony ${ }^{37}$.

Traugutt rozpoczynał dzień od modlitwy. Spotykał się m.in. z Marianem Dubieckim, Józefem Kajetanem Janowskim, Cezarym Morawskim, braćmi Karolem i Wacławem Przybylskimi, którzy odwiedzali go, czasem sam wychodził

${ }^{33}$ M. Dubiecki, $d z$. cyt., s. 137. Podobnie zeznał przed Komisją Śledczą Zdzisław Janczewski. Zob. Z. Janczewski, K. Majewski, O. Awejde, W. Daniłowski, Zeznania śledcze o powstaniu styczniowym, oprac. i przygotował do druku S. Kieniewicz, Wrocław 1956, s. 70.

${ }^{34}$ Proces Romualda Traugutta, t. 2, cz. 1, s. 208-212 (zeznania A. Kręckiego, K. Przybylskiego), s. 237-238 (zeznania K. Przybylskiego, Z. Wierzbowskiej, M. Płacheckiej), s. 258-259 (zeznania A. Wróblewskiej).

${ }_{35}^{35}$ M. Dubiecki, dz. cyt., s. 137.

${ }^{36}$ Proces Romualda Traugutta, t. 2, cz. 2, s. 186 (zeznania H. Kirkorowej).

${ }^{37}$ M. Dubiecki, dz. cyt., s. 138. 
by spotkać się na mieście. Z mieszkania Kirkorowej przy ul. Smolnej kierował powstaniem przez ostatnich kilka miesięcy.

Masowe aresztowania w styczniu $1864 \mathrm{r}$. oraz natychmiastowe śledztwo bardzo szybko doprowadziły Rosjan do ośrodka dyspozycyjnego, jakim było mieszkanie Kirkorowej. Na przełomie marca i kwietnia 1864 r. aresztowani zostali najbliżsi współpracownicy Traugutta. Wśród nich znalazł się m.in. Karol Przybylski i Cezary Morawski. Przybylski podczas przesłuchania załamał się i zaczął sypać. Doszło więc niebawem do kolejnych aresztowań. W nocy z 10 na 11 kwietnia 1864 r. aresztowano dyktatora. Natomiast Kirkorowa, na razie nie zadenuncjowana i nie poddana rewizji, zdążyła jeszcze oddać papiery Traugutta Franciszce Kryt, z poleceniem przekazania ich dalej. Następnej nocy, z 11 na 12 kwietnia, na skutek obciążających zeznań Karola Przybylskiego, aresztowana została Kirkorowa. Przeprowadzona w jej mieszkaniu rewizja niczego nie ujawniła. Kirkorowa przesłuchiwana na Pawiaku zachowała postawę godną i nieugiętą ${ }^{38}$.

Kirkorowa podczas przesłuchania odmówiła składania zeznań, więc wtrącono ją do lochu. Po dziewięciu dniach zasłabła. W czasie, gdy przebywała w lochu, Komisja Śledcza przesłuchiwała jej służbę i właściciela domu przy ul. Smolnej. Przeciwko Kirkorowej zgromadzono nowe dowody. Do aresztu trafił także jej brat stryjeczny Feliks Majewski. Dwa dni po wyjściu z lochu Kirkorowa napisała list do matki z prośbą o ratowanie „Pana Michała” i ostrzeżenie osób skompromitowanych podczas śledztwa ${ }^{39}$. List ten nie dotarł jednak do adresatki, bowiem przejęli go żandarmi rosyjscy. Rozpoczęły się kolejne aresztowania. Dnia 29 kwietnia 1864 r., na skutek obciążających zeznań Karola Przybylskiego, aresztowano doktora Włodzimierza Dybka ${ }^{40}$. Następnego dnia do aresztu trafiła Ludwika Majewska, matka Kirkorowej, która nie mając z kim zostawić kilkuletniego Władzia, zabrała go ze sobą na Pawiak. W dniu 1 maja aresztowano Franciszkę Kryt. Podczas kolejnych przesłuchań i konfrontacji Kirkorowa nie dała się złamać. Jej matkę trzymano w więzieniu do 8 czerwca, a następnie zwolniono i oddano pod tajny dozór policyjny. Podczas śledztwa udało się złamać Franciszkę Kryt, która zeznała, iż wzięła od Kirkorowej papiery, i na jej polecenie przekazała je nieznajomej osobie ${ }^{41}$. Komisja Śledcza dołączyła sprawę Kirkorowej do procesu Traugutta i członków Rządu Narodowego ${ }^{42}$. W dniu 19 maja 1864 r. przewieziono dyktatora i innych wraz z nim oskarżonych do X Pawilonu Cytadeli Warszawskiej. Kilka dni później trafiła tam również Kirkorowa, osadzono ją nad celą Traugutta. W celi obok niej więziony był Jan Jeziorański, komisarz Komunikacji przy Sekretaria-

38 Proces Romualda Traugutta, t. 2, cz. 1, s. 287-288 (zeznania H. Kirkorowej).

39 Tamże, t. 2, cz. 2, s. 330-333 (list H. Kirkorowej do matki).

40 Tamże, t. 2, cz. 2, s. 15 (zeznania K. Przybylskiego).

${ }^{41}$ Tamże, t. 2, cz. 2, s. 302-303 (zeznania F. Kryt), s. 303 (zeznania H. Kirkorowej).

42 E. Halicz, Proces Romualda Traugutta, „Wojskowy Przegląd Historyczny” 1957, nr 1, s. 242-263. 
cie Stanu Rządu Narodowego. Kirkorowa, jak wynika z listów Jeziorańskiego do żony, nawet w więzieniu dbała o spokój dyktatora.

Mam sąsiadkę jakąś - pisał Jeziorański do żony - która czy liter nie zna, czy co ale zupełnie się z nią rozmówić nie można przez mur lecz pod nią siedzi Traugutt, a z nim czasem telegrafuję ale baba zazdrosna nie da, zaraz rozmyślnie wali w mur i przeszkadza i ona biedna ${ }^{43}$.

Dyktator trzymany był w zupełnej izolacji, spacery odbywał samotnie.

Kirkorową oskarżono o to, że ,zezwalała ważniejszym działaczom buntu zbierać się z mieszkającym u niej Romualdem Trauguttem na narady, których przestępcze znaczenie było jej w pełni znane”, „współdziałała z przestępcami przez przechowywanie, przesyłkę i wreszcie osobiste przekazywanie według przeznaczenia korespondencji przestępców”, ,,po aresztowaniu Traugutta przekazała nieznanej kobiecie do ukrycia znajdujące się u niej na przechowaniu papiery przestępców”, „w czasie przebywania w więzieniu usiłowała w liście do swojej matki, napisanym w sekrecie, ostrzec niektórych ujawnionych podczas śledztwa przestępców”, „wydała według jej własnego przyznania się dwóm powstańcom, którzy się do nie zgłosili o pomoc, rewolwer pozostawiony u niej przez Tadeusza Komara, który wyjechał za granicę"44.

Sąd Wojenny Polowy w dniu 19 lipca 1864 r. wydał wyrok. Traugutta i czterech członków Rządu Narodowego (Jana Jeziorańskiego, Rafała Krajewskiego, Romana Żulińskiego, Józefa Toczyskiego) skazano na karę śmierci. Wyrok wykonano 5 sierpnia na stokach Cytadeli Warszawskiej w obecności kilkudziesięciotysięcznego tłumu mieszkańców Warszawy. Pozostałych z procesu Traugutta skazano na katorgę albo zesłanie ${ }^{45}$. Kirkorową skazano na osiedlenie na Syberii do mniej odległych miejscowości, z pozbawieniem wszystkich praw. Audytoriat Polowy, jako wyższa instancja, zaostrzył wyrok Kirkorowej podwyższając karę do 8 lat ciężkich robót na Syberii. Teodor Berg, namiestnik Królestwa Polskiego, wyrok konfirmowat ${ }^{46}$.

W grupie zesłańców syberyjskich Kirkorowa znalazła się w gronie pięćdziesięciu osób. Wśród nich byli wszyscy towarzysze z procesu Traugutta skazani na katorgę. Znajdował się w niej m.in. Tomasz Ilnicki, urzędnik Banku Polskiego i kasjer Rządu Narodowego, Marian Dubiecki, któremu Audytoriat Polowy

43 J. Jarzębowski, Jan Jeziorański. Zapomniany bohater 1863 roku, słowo wstępne i oprac. Z. Jeziorański (Jan Nowak), Londyn 1974, s. 138.

${ }^{4}$ Wyrok Audytoriatu w sprawie „Rządu Narodowego" w 1864 r., thum. i oprac. H. Cederbaum, Warszawa 1916, s. 9-10; H. Cederbaum, Powstanie styczniowe. Wyroki Audytoriatu Polowego z lat 1863, 1864, 1865 i 1866, Warszawa-Lublin-Lódź-Kraków 1917, s. 151; Proces Romualda Traugutta, t. 3, s. 93 (wyrok Sądu Polowego), s. 160-161 (orzeczenie Audytoriatu Polowego w sprawie R. Traugutta i 22 osób z nim sądzonych).

${ }^{45}$ E. Halicz, dz. cyt., s. 260-261.

${ }^{46}$ Proces Romualda Traugutta, t. 3, s. 171 (konfirmacja wyroku przez T. Berga). 
zamienił karę śmierci na katorgę na Syberii, Tomasz Burzyński, referent Wydziału Spraw Wewnętrznych Rządu Narodowego, Władysław Bogusławski, przyszły krytyk teatralny, wnuk Wojciecha Bogusławskiego, Benedykt Dybowski, profesor Szkoły Głównej, Jan Muklanowicz, aptekarz, siostry Barbara i Emila Guzowskie oraz młodzi studenci, m. in. Roman Frankowski, August Kręcki, Gustaw Paprocki, Kazimierz Hanusz, Edward Trzebiecki i Zygmunt Sumiński. Wśród zesłańców znajdował się także Feliks Majewski, brat stryjeczny Kirkorowej ${ }^{47}$.

Skazani, drogę z Warszawy do Moskwy, z postojem w Petersburgu, przebyli koleją. W Moskwie część zesłańców rozmieszczono w twerskiej części pałacu gubernatorskiego, pozostałych w tzw. Kałamażnym Dworze, czyli w dawnych stajniach koszar artyleryjskich przerobionych na cele więzienne. Znalazła się tu Kirkorowa i siostry Guzowskie.

Panie te - jak pisze Tomasz Burzyński - korzystając z wizyty gubernatora czy jakiegoś innego dygnitarza, skarżyły się, ze ich oddzielono od znajomych i prosiły o przeniesienie, albo ich do twerskiej części, lub nas do Kałamażnego Dworu. To drugie żądanie zostało uwzględnione ${ }^{48}$.

Kolejnym etapem był Niżny Nowogród, skąd następnie przewieziono zesłańców kibitkami do Tobolska. Kirkorowa w podróży tej za towarzysza miała Romana Frankowskiego. W Tobolsku zapadła decyzja, że skazańcy z procesu Traugutta mają odbyć karę w guberni irkuckiej. Dalszym etapem był Tomsk, następnie Krasnojarsk, skąd wyruszono do Kańska. Po prawie siedmiomiesięcznej „podróży” zesłańcy dotarli do Irkucka ${ }^{49}$.

Kirkorowa trafiła do Usola, do którego władze rosyjskie zsyłały skazanych na ciężkie roboty przestępców politycznych i kryminalnych. Znajdowały się tu koszary dla więźniów pracujących przy odparowywaniu soli ze znajdujących się tam złóż solanki ${ }^{50}$. W Usolu, oprócz Kirkorowej i sióstr Guzowskich, przebywała Józefa Gudzińska, zesłana tu za udzielenie schronienia jednemu z agentów Rządu Narodowego ${ }^{51}$. Tutaj przyszło też Kirkorowej spędzić pierwszą na zesłaniu Wigilię Bożego Narodzenia ${ }^{52}$. W czerwcu 1866 r. na mocy amnestii z okazji zaręczyn

${ }^{47}$ B. Dybowski, Pamiętnik od roku 1862 zaczqwszy do roku 1878, Lwów 1930, s. 25-26; tenże, O Syberii i Kamczatce, Warszawa-Kraków 1912, s. 102.

${ }^{48}$ T. Burzyński, Wspomnienia z czasów młodości, [w:] Wydawnictwo materiałów do historii powstania 1863-1864, t. 4, Lwów 1894, s. 223.

49 B. Dybowski, Pamiętnik, s. 30.

50 A. Brus, Usol - szczególne miejsce, szczególni ludzie, [w:] Zesłańcy postyczniowi w Imperium Rosyjskim. Studia dedykowane Profesor Wiktorii Śliwowskiej, red. E. Niebelski, Lublin-Warszawa 2008, s. 141-154.

${ }^{51}$ W. Caban, L. Michalska-Bracha, Kobiety powstania styczniowego na Syberii. Zestanki do Usola i Kunguru, [w:] Postawy i aktywność kobiet w czasie powstania styczniowego 1863-1864 (na tle polskich konspiracji i działalności powstańczej doby zaborowej), pod red. T. Kulak, J. Dufrat, M. Piotrowskiej-Marchewy, Wrocław 2013, s. 174-176.

${ }^{52}$ W. Nowakowski, Wilia w Usolu na Syberii 1865 roku, Kraków 1894, s. 3. 
rosyjskiego następcy tronu Aleksandra z księżniczką duńską Dagmarą, Kirkorowej skrócono karę ciężkich robót z ośmiu do czterech lat ${ }^{53}$.

Przebywając w Usolu 8 kwietnia 1867 r. Kirkorowa otrzymała wiadomość o unieważnieniu jej małżeństwa z Adamem H. Kirkorem. W przesłanym jej dokumencie unieważniającym związek, stwierdzono, iż małżeństwo ,zgodnie z przedstawionymi dokumentami i po przeprowadzeniu dochodzenia na podstawie prawa kanonicznego i cywilnego zostało unieważnione [...]". W dalszej części dokumentu informowano, że także i ona ,jest wolna i nie ma przeszkód prawnych, aby wstąpić miała w związek małżeński z drugą osobą" ${ }^{54}$. Kolejne tygodnie zesłania przyniosły następne ulgi w odbywaniu kary. Manifest z 17 maja 1867 r. wydany $\mathrm{z}$ racji ślubu następcy tronu, wprowadzał drugą amnestię, która wielu zesłańcom zamieniała katorgę na osiedlenie, nielicznym zezwoliła na powrót do kraju. Kirkorowa otrzymała wówczas pozwolenie na zamieszkanie w Irkucku5

Kirkorowa po przybyciu do Irkucka próbowała powrócić do gry aktorskiej. Agaton Giller pisze, że

zaangażowała się u miejscowego entreprenera Krauzego, ale na pierwszym przedstawieniu wybrała rolę młodej dziewczyny, wcale dla niej nieodpowiednią. Doznawszy okropne „fiasco”, wysykana przez publiczność, musiała wyrzec się tego chleba i entreprener nie odważył się zatrzymać jej ${ }^{56}$.

Wieść o jej niepowodzeniach scenicznych szeroko rozeszła się wśród zesłańców. Wspominał o nich także Wacław Lasocki, pisząc, że Kirkorowa ,raz tylko próbowała wystąpić publicznie jako artystka w teatrze irkuckim, ale się ten występ nie powiódł i zmusił ją do wycofania się ze sceny"57.

Społeczność zesłańcza odtrącała Kirkorową. Kojarzono ją jako kochankę Syrokomli, dla której poeta ,włóczył się po miastach i miasteczkach, wędrując za trupą aktorów" 58 . Los jednak uśmiechnął się do niej jeszcze raz. W Irkucku poznała zesłańca Antoniego Pióro, za którego niebawem wyszła za mąż. Pióro był właścicielem majątku Pohostyszcze w powiecie orszańskim, który stracił w wyniku konfiskaty. Aresztowany został za udział w powstaniu i za ,ukrywanie zbiegłego z bandy Budziłowskiego oraz sprzyjanie z jego pomocą organizowaniu

${ }_{53}$ W. Śliwowska, Syberia w życiu i pamięci Gieysztorów - zesłańców postyczniowych. WilnoSybir-Wiatka-Warszawa, Warszawa 2000, s. 294.

${ }^{54}$ Gosudarstwiennyj Archiw Irkutskoj Obłasti, zesp. 24, inw. 3, pudło 48, poszyt 247, k. 1-6. Informacja na podstawie Kartoteki Zesłańców Syberyjskich w Instytucie Historii Polskiej Akademii Nauk w Warszawie.

55 W. Śliwowska, dz. cyt., s. 223.

${ }^{56}$ A. Giller, Spis Polaków będacych w Usolu w ciężkich robotach od 17 kwietnia 1866 do września 1868 roku, Poznań 1872, s. 170.

57 W. Lasocki, Wspomnienia z mojego życia, t. 2: Na Syberii, przygotowali do druku M. Janik i F. Kopera, Kraków 1934, s. 309; B. Jędrychowska, Polscy zesłańcy na Syberii 1830-1883. Dziatalność pedagogiczna, oświatowa i kulturalna, Wrocław 2000, s. 132.

${ }^{58}$ W. Caban, L. Michalska-Bracha, dz. cyt., s. 177. 
buntu w powiecie orszańskim i formowaniu buntowniczych szajek". Skazano go na 10 lat ciężkich robót w twierdzach. Pióro korzystał z tych samych amnestii co Kirkorowa. Po przybyciu do Irkucka objął filię sklepu kolonialno-spożywczego w Maczy. W prowadzeniu sklepu pomagała mu żona ${ }^{59}$.

W marcu 1873 r., na mocy ukazu Aleksandra II z września 1872 r., Kirkorowa wyjechała z mężem do guberni permskiej. Zamieszkiwali tu pod dozorem policyjnym, nadal też byli pozbawieni praw stanu, które przywrócono im na podstawie ukazu z 9 stycznia 1874 r., zwalniając jednocześnie z dozoru policyjnego. Po powrocie z zesłania zamieszkali w Smoleńsku, gdzie prowadzili sklep przemysłowy $^{60}$. Latem 1874 r. Kirkorowa odwiedziła Warszawę. Spotkała się wtedy z Moniką Dmitriew, córką rosyjskiego generała, podczas powstania zaangażowaną w opiekę nad więźniami politycznymi. Dmitriew zarabiała jako nauczycielka lekcjami prywatnymi, a od 1870 r. prowadziła własną szkółkę dwuklasową ${ }^{61}$. Po zesłaniu Kirkorowej zaopiekowała się Ludwiką Majewską i kilkuletnim Władysławem. Kirkorowa podczas spotkania z Dmitriew opowiadała o przedsiębiorstwie handlowym w Smoleńsku, prowadzonym razem z mężem ${ }^{62}$.

Z korespondencji Moniki Dmitriew z Marianem Dubieckim wynika, że Kirkorowa będąc jeszcze na zesłaniu interesowała się losem matki i swojego wychowanka Władysława. Nie zgadzała się z Moniką Dmitriew by chłopiec zdobywał zawód ślusarza ${ }^{63}$. Gdy z zesłania powrócił Zygmunt Sumiński i Włodzimierz Dybek, Kirkorowa za ich pośrednictwem próbowała uzyskać pomoc dla chłopca. Korespondowała w tym celu z Dmitriew, starając się, w miarę swoich możliwości, zapewnić wychowankowi właściwe wykształcenie ${ }^{64}$. Po śmierci Ludwiki Majewskiej w 1872 r. chłopcem zaopiekował się jego ojciec, bliżej nieznany dr Władysław Leszczyński. Kirkorowa zrzekła się opieki nad dzieckiem ${ }^{65}$.

Ostatnie lata jej życia toną w mrokach dziejów. Po śmierci Antoniego Pióro w 1890 r. Kirkorowa zamieszkała w Witebsku. Wiadomo, że utrzymywała serdeczny kontakt z Bronisławą Jeziorańską, córką Jana, straconego razem z Trauguttem i członkami Rządu Narodowego, która wyszła za mąż za Stanisława Romeyko-Hurko, siostrzeńca Antoniego Pióro ${ }^{66}$. Kontakt utrzymywała też

59 W.A. Djakow, Diejatieli russkogo i polskogo oswoboditielnogo dwiżenija w carskoj armii 1856-1865 godow. Biobibliograficzeskij stowar, Moskwa 1967, s. 143; W. Śliwowska, dz. cyt., s. 294.

${ }^{60}$ W. Śliwowska, dz. cyt., s. 223, 294.

${ }^{61}$ D. Wawrzykowska-Wierciochowa, Rosyjskie przyjaciótki narodu polskiego w latach sześćdziesiatych XIX stulecia, „Kwartalnik Instytutu Polsko-Radzieckiego” 1956, nr 3-4, s. 142-156; P. Łossowski, Z. Młynarski, Rosjanie, Białorusini i Ukraincy w powstaniu styczniowym, Wrocław 1959, s. 156-157.

${ }^{62}$ Biblioteka Jagiellońska w Krakowie [dalej: BJ], rkps Przyb. 206/73 (list M. Dmitriew do M. Dubieckiego z 22 lipca 1874 r.).

${ }^{63}$ Tamże, rkps Przyb. 206/73 (list M. Dmitriew do M. Dubieckiego z 30 lipca 1873 r.).

${ }^{64}$ Tamże, rkps Przyb. 206/73 (list M. Dmitriew do M. Dubieckiego z 17 maja 1870 r.).

${ }_{65}$ Tamże, rkps Przyb. 206/73 (list M. Dmitriew do M. Dubieckiego z 16 stycznia 1874 r.).

${ }^{66}$ J. Jarzębowski, $d z$. cyt., s. 7; F. Ramotowska, dz. cyt., s. 485. 
z Marianem Dubieckim, chociaż nie zachowała się ich korespondencja. Interesowała się życiem kulturalnym i artystycznym. Tuż przed śmiercią przekazała do zbiorów etnograficznych Muzeum Przemysłu i Rolnictwa w Warszawie swoje pantofelki baletowe używane w teatrze wileńskim ${ }^{67}$. Kirkorowa zmarła 5 stycznia 1900 r. w Witebsku. W prasie ukazało się zaledwie kilka jednozdaniowych wzmianek o jej śmierci ${ }^{68}$.

Kirkorowa już za życia wzbudzała wiele kontrowersji. Sławę i rozgłos przyniosła jej nie tylko kariera aktorska, ale przede wszystkim pełna poświęcenia rola opiekunki dyktatora, którą przyszło jej odegrać podczas powstania styczniowego. Była to najtrudniejsza rola w jej życiu, za którą zapłaciła bardzo wysoką cenę - zesłanie na Syberię.

\section{Emil Noiński}

\section{GUARDIAN OF THE DICTATOR. THE FATE OF HELENA KIRKOROVA (1828-1900) IN THE JANUARY UPRISING AND SIBERIAN EXILE}

$\mathrm{H}$ elena from Majewski Kirkorowa was an actress of the Vilnius and Krakow scene. She started her career in Vilnius. After marrying Adam Honory Kirkor, archaeologist, publisher, publicist, editor and theater critic, she got involved in an affair with the poet Ludwik Kondratowicz (Władysław Syrokomla). After parting with her husband, she came to Krakow, where she performed in the theater of Juliusz Pfeifra. Then she came to Warsaw. She was quickly involved in conspiracy. There was a courier of the National Government, transporting messages and commands across the border. Romuald Traugutt, the last dictator of the January Uprising, was arrested in her apartment at Smolna Street in Warsaw. She was soon imprisoned and Kirkorowa. The court sentenced her to settle in Siberia with the deprivation of all rights, which soon turned into eight years of hard work. In August 1864, Kirkorowa was deported to Siberia. During the exile, she married Antoni Pióro. After returning from exile, she lived in Vitebsk, where she died on January 5, 1900.

Słowa kluczowe: Helena Kirkorowa, aktorka, powstanie styczniowe, zesłanie syberyjskie

Keywords: Helena Kirkorowa, actress, January Uprising, Siberian exile

${ }^{67}$ „Kurier Warszawski” 1900, nr 54, s. 2.

68 „Słowo” (Warszawa) 1900, nr 30, s. 3; „Tygodnik Ilustrowany” 1900, nr 8, s. 158; „Kurier Warszawski” 1900, nr 38, s. 5; „Gazeta Kaliska” 1900, nr 32, s. 3. 


\section{BIBLIOGRAFIA}

\section{Źródła:}

Archiwum Państwowe w Piotrkowie Trybunalskim. Oddział w Tomaszowie Mazowieckim Akta Stanu Cywilnego Parafii Rzymskokatolickiej w Białej, sygn. 5.

Biblioteka Narodowa w Warszawie

E. Deryng, Z pamiętników aktora wileńskiego, rkps akc. 7882.

Koźmian A. E., Listy, t. 3, Lwów 1894.

Moraczewska B., Dziennik, Poznań 1911.

Proces Romualda Traugutta i czlonków Rzadu Narodowego. Akta Audytoriatu Polowego z lat 1863/1864, t. 1-3, pod red. E. Halicza, Warszawa 1960.

\section{Opracowania:}

Berg M., Zapiski o powstaniu polskim 1863 i 1864 roku i poprzedzajacej powstanie epoce demonstracji od $1856 r$ r. t. 3, Kraków 1899.

Caban W., Michalska-Bracha L., Kobiety powstania styczniowego na Syberii. Zestanki do Usola i Kunguru, [w:] Postawy i aktywność kobiet w czasie powstania styczniowego 1863-1864 (na tle polskich konspiracji i działalności powstańczej doby zaborowej), pod red. T. Kulak, J. Dufrat, M. Piotrowskiej-Marchewy, Wrocław 2013.

Dubiecki M., Romuald Traugutt i jego dyktatura podczas powstania styczniowego 1863-1864, Kijów 1911.

Kirkor S., Na Syberii. Dalszy przyczynek do historii życia Heleny Kirkorowej, „Wiadomości” 1965, nr 51-52.

Kirkor S., Od Syrokomli do Traugutta. Tragiczna dola Heleny Kirkorowej, „Wiadomości” 1962, nr 51-52.

Puchalska J., Kobiety, które zmienity świat, Warszawa 2016.

Ramotowska F., Kirkorowa 2. v. Piórowa z Majewskich Petronela Helena, działaczka powstania 1863 r., [w:] Polski Stownik Biograficzny, t. 12, Wrocław-Kraków-Warszawa 1966-1967.

Śliwowska W., Syberia w życiu i pamięci Gieysztorów - zesłańców postyczniowych. Wilno-Sybir-WiatkaWarszawa, Warszawa 2000.

Wilski Z., Polskie szkolnictwo teatralne 1811-1944, Wrocław-Warszawa-Kraków-Gdańsk 1978.

Witkowski M., Syrokomli wycieczka po swojszczyźnie, [w:] Literackie przystanki nad Warta, pod red. Z. Szweykowskiego, Poznań 1962. 